\title{
Of Lady-killers and 'Men Dressed As Women’: Soap Opera, Scapegoats and the Mexico City Police Department
}

\author{
Vek Lewis, University of Sydney
}

\begin{abstract}
Examples of exaggeration are to be found in the way in which alterity, cultural, religious, or any other sort of difference become objects of fantasies and fears. The actors who are assumed to embody them are likely to become scapegoats, to the extent that they are frequently attributed a virtual violence that is almost natural or innate, whereas in reality they are very far from any such thing, if such a thing were to exist. (Wieviorka 2003: 111)
\end{abstract}

\section{Introduction}

A string of murders in real-life Mexico City whose perpetrator cannot be found, a highrating family drama whose half-year long escalating whodunnit draws to a dramatic close, a police investigation whose top brass come up with an assortment of useless leads, a fictional transvestite who gains the trust of women only to kill them, a raid on travesti prostitutes in the hunt for the evasive killer, an ex-lucha libre wrestler known in the circuit as 'The Silent Lady' who is eventually fingered as the guilty party... The lines between reality and fantasy in contemporary Mexican life are often not only unclear but can also lead to a fear-driven crosshatching of fiction and real life events in the scandalized public imagination. All the elements in this particular story are worthy of a serial melodrama. This article explores the intersections between the insertion of narrative elements of the highly successful Mexican primetime serial La madrastra (The Stepmother), from 2005, into popular consciousness and police mishandling of the case of a serial killer dubbed mataviejitas — the old lady-killer.

Telenovelas are watched by the great bulk of the population in Mexico—not just 
women — and especially the popular classes. In saying this, I understand the Mexican police as viewers of the representations and participants in the talk that arose in the wake of the telenovela's denouement, a critical tactic that places them firmly within the mainstream of the viewing public. This article raises an important question: do symbolic representations have material consequences for specific groups of people in society, in this case, travestis? And if so, how does this occur?

The term travesti, as Mauro Cabral and Paula Viturro state, is used to refer to

those persons who, having been assigned the masculine gender at birth, identify themselves in different versions of femininity, and who may or may not surgically or hormonally modify their bodies. [Travesti] possesses a particular political specificity, in that it unites a generalized condition of social vulnerability, an association with sexual work, the exclusion of basic rights, and the recognition of the same as a political identity. (2006: 270)

Although these scholar-activists refer to Argentina, travestis are found in many parts of Latin America, including Mexico. Their lives and identities have been documented and studied at length in the last decade by both Latin American and non-Latin American ethnographers. The work of Annick Prieur (1998), for example, offers a detailed picture of the connection between Mexican travestis' gender and sexuality and their class origins, as well as their involvement in informal prostitution. Likewise, Mexican anthropologist César González Pérez offers a view into the realities of travesti existence in Colima, Mexico, in his 2003 study on travestidos gays. His study commences with an examination of Mexico’s Judeo-Christian heritage and the condemnation of sexual diversity. It also profiles the emergence of travestismo in relation to medico-legal discourses of deviance. He demonstrates that travestismo is more socially accepted when it is confined to the stage, in other words, for performance and entertainment purposes. Outside this context it is subject to much opprobrium and social stigma. Colima's travestis experience ostracism in various domains and live on the edges of institutional life. This is also the case for travestis in other parts of Mexico. González Pérez's work, and that of other scholars, provides useful information about the cultural framing of travestis and their marginalisation, elements that will be touched on throughout this article. In recent years travestis have obtained considerable, although frequently fraught, social and political visibility. Travestis in Latin America comprise a segment of a set of sexually diverse populations, which includes gays and lesbians, whose place in culture is often imperilled socially, economically and politically. It is perhaps unsurprising that Mexican popular media presently responds to this visibility in 
ways that are themselves not unproblematic. Representations of sexual minorities, while under-explored in the literature on representations by Latin American and Latin Americanist scholars, provide a key link to the essential question of how the limits of knowledge around certain subjects are produced and reproduced in contemporary cultural contexts and the impacts such production has.

In general, the issue of representation, these days, is infrequently addressed, as the connections between cultural productions and their reception have been so complicated by cultural critics as to appear to be impossible to predict. Stuart Hall has famously shown that the meanings encoded in productions as intended by their makers are not necessarily identical to the meanings decoded by viewers, and that production does not end when a piece of television has been edited and shown. Meanings are continually produced and reproduced (1980: 128-29). Representations, once released into the public realm, might be open to a multitude of interpretations, so what is the sense in addressing them here? While asymmetries of meaning may occur en route in the dispersal of a product and its reception, and oppositional or counter-hegemonic readings are always a possibility, this cannot discount instances in which the knowledge frameworks of dominant culture align with the viewing public's own available frameworks, in which the visualising and interpreting of representational phenomena retain real symmetry.

These knowledge frameworks, or conceptual models, are traceable in media texts and also the talk generated around them. Knowledge relates not simply to encoded information, but also the beliefs that people hold about phenomena. These beliefs may be implicit, but they are shared by groups of viewers and readers who comprise what critical discourse theorist Teun van Dijk calls an ‘epistemic community’ (2003: 86). Such communities share certain mental models and acquire strategies of interpretation from the discursive forms that structure their social and informational worlds. Media texts may construct, authorise and activate established models of perception in their representational forms, as well as suggest certain 'routes' of interpretation. As van Dijk further notes, in the realm of representations, the following pattern applies: $\mathrm{X}$ represents $\mathrm{Y}$ for $\mathrm{Z}$. $\mathrm{X}$ is the representation, $\mathrm{Y}$ is the thing represented by $\mathrm{X}$ (usually something concrete in the world) and $\mathrm{Z}$ is the person or group that reads the representation (91). The power of the preferred or hegemonic reading, based as it is on shared knowledge constructs about the $\mathrm{Y}$ term, here, travestis, is important in evaluating the political 
consequences of representations. A consideration of the telenovela La madrastra, the parallel criminal case, public talk about both and police actions in engineering a swoop on sex working travestis, provide the occasion for a thoroughgoing reflection on the issue of representation, modes of knowledge and their effects.

In the following section I outline major critical approaches to the telenovela genre. I then address the novela, La madrastra, sketch out its main features and demonstrate how it fits into the typical novela form. (Footage from the final cliffhanger episode of La madrastra that crystallises the moment of the representation of cross-dressing is available to readers of this article as a supplementary file.) I address the role of Televisa, the company that produced La madrastra, with respect to its depictions of sexual minorities, depictions that partake of a long history of mass cultural and juridical anxiety around cross-gendering, the kind of anxiety that underwrites La madrastra's visions. Next I speculate about viewer positions, referring to several on-line responses by the public vis-à-vis cross-dressing and travestis after the final episode of $L a$ madrastra was screened. Finally, I examine the mataviejitas case, in order to ask some questions about how the codes of interpreting fiction and 'real-life' events in Mexican media interact and merge and may impact not just on peoples’ perceptions but also lives.

\section{Critical Approaches to the Telenovela Form}

Since the 1980s, scholars have studied the insertion of telenovelas into daily life, as Ana López (1995) notes. This regards the function of the telenovela in terms of the 'modernisation' of Latin American societies and the complicated relationship between production and reception. Jesús Martín-Barbero has centred on these questions in several works, beginning with his landmark study De los medios a las mediaciones (1987), which posits that the telenovela, like other popular forms, is a site of mediations between the forces of production and reception. As López states, responding to MartínBarbero's insights, the telenovela 'bears the marks of TV's commercial imperatives and responds to the demands of cultural habits and specific ways of seeing which are in a constant state of transformation and adaptation' (1995: 257).

Telenovelas are hugely popular throughout Latin America; at times twelve different serials are screened each day, from dawn to dusk. This significantly impacts to frame the way publics in Latin America see not only themselves but also the rest of the world. 
López labels the novela a melodramatic form par excellence, whose organising mode is the principle of terminal moral forces that run through the social fabric (261).

Telenovelas are organised around figures of excess, often employing hyperbole, oxymoron and antithetical elements counterposed, as Aprea and Martínez Mendoza note (1996: 21). These are the typical characteristics of melodrama. Mexican novelas, as López and others indicate, are notorious for their Manichean vision of the worldproposing a set of duelling dualisms, good and evil, saint and sinner and so on. Although they are traditionally bereft of references to the real world in the sense of politics or economics, the picture of extended families and tightly knitted social groups evinces a degree of moral certainty that is only threatened by certain outside polarising forces that may intrude on family life. In the typical telenovela, Aprea and Martínez Mendoza observe, everything revolves around a heterosexual couple at the centre of the story (1996: 24). Often there is a wedding, or a planned wedding, which certain forces may interrupt or complicate. Desires, and the persistence of desires, drive the plot. Yet only desires properly contained within the monogamous heterosexual couple inevitably succeed and are trumpeted.

The telenovela encourages a high degree of viewer identification and complicity, and often develops its themes in line with public interest, as well as, commonly, the presence of a major star. The good-natured protagonists are key; the heroine, moreover, obtains a more primordial place in the plot than the hero. The heroine is the chief point of public identification. As José Ignacio Cabrujas affirms:

La protagonista debe lucir desvalida y tener un rostro de candor. Debe ser un 'ser absoluto,' construida sobre el amor a la abuela, a los niños, al perro, carece de odios. Es honrada, aunque puede saltarse una ley injusta por una causa noble. Es una persona normal que apunta en todo a lo sublime. ${ }^{1}$ (2002: 56-57)

These characteristics place the female protagonist in the realm of the community; she is a figure of solidarity and strength and given over to public identification. She is 'one of us,' as Cabrujas asserts, unlike the villain or villains, who are invariably not part of the community, or may be outsiders. Further, as Cabrujas argues, 'Toda heroína encarna la esencia del pueblo y la elabora una conducta superior al espectador' (57) and, as such,

\footnotetext{
1 'The heroine should appear helpless and have a sincere face. She should be a complete being, constructed on the basis of her love towards her grandmother, children, dog, lacking in hatred. She is honourable, although she may break an unjust law for the sake of a noble cause. She is a normal person who fulfils the sublime in all she does.' This translation, and all translations here, are mine.
} 
she is viewed as a guide, and a presence in viewer's lives. ${ }^{2}$

The important insertion of the telenovela into everyday life has a traceable genealogy. As Martín-Barbero illustrates in 'Memory and Form in the Latin American Soap Opera,' its ancestors are the folletín - the newspaper serial, written day-to-day, subject to reader response, a '(con)fusion of fiction and life' and the popular melodramatic cinema of the forties and fifties, which emotively depicted the kinship, relationships and rivalries of everyday existence (1995: 277). Viewers classically derive a varied set of pleasures from the genre- events may be fantastical and over-the-top, but the suspension of disbelief involved in viewer participation, the watching and reading 'as if it were real' is significant. Telenovelas, which often run to nine months, commonly have the attenuated pace of life, 'the slow, cyclical rhythms of family life' (Allen 1995: 11). The stories that they tell become a matter of public interest and interrogation. There are only two days of the week in which telenovelas do not run-those annoying weekends—and people are left hanging to mull over what has happened, what will happen and what will be the consequences of possible future developments.

Allen talks of the teleological thrust of the telenovela. For Allen, the drive towards closure

privileges the final episodes institutionally, textually, and in terms of audience expectation and satisfaction. And telenovelas depend, for their impact, on an intense play of tensions and expectations, expectations that are linked to the conventions of the genre and the structures of everyday life, which together point to a horizon of expectations, based on viewer's previous viewing experiences as well as their own life experiences. The ending of the telenovela is heavily promoted, and, in the case of particularly popular telenovelas, becomes the subject of anticipatory public and private discourse. (1995: 23)

Telenovelas have a closed format - they must come to an end. As Allen further indicates: 'closed serials offer viewers the opportunity to look back upon the completed text and impose on it some kind of moral or ideological order' (23). This moral order is intimately connected to melodrama, which dramatises and makes significant every moment. Questions raised are of the following type: what does this mean? Why is this happening? What is the hidden, underlying cause or reason? Christina Slade observes that 'when it comes to understanding the human, emotional and domestic life of ... Latin America, telenovelas are the privileged forms’ (2003: 8). Telenovelas have

\footnotetext{
2 'All heroines incarnate the essence of the people, and this essence is detailed via behaviour superior to that of the viewer.'
} 
centrality in people's lives in Mexico and elsewhere and although, as Martín Barbero relates, they are often 'laden with heavy narrative schema and complicitous, deceptive ideological inertia,’ meanings are not simply imposed on viewers (Barbero 1995: 281). He further signals: 'The full meaning and pleasure are found not just in the text, but more in the discussion of the family, neighborhood, workplace and friend networks' (2000: 156-57). Many studies thus move outside textual analysis and seek to locate telenovelas ethnographically. For telenovelas, in the words of Christina Slade, 'are part of the texture' of the everyday. Fictional telenovela narrative for Slade is used as a sounding board for ethical issues that are difficult to discuss in the first person (2003: 14). They thus form the basis for talk on wider events.

\section{Televisa's La madrastra}

All these features are relevant to the Televisa novela La madrastra. This telenovela, twice remade and based on an original teleseries from 1980s Chile, commenced in February 2005 and finished up in August of the same year. It centres on María, who is sentenced to life in prison after being wrongfully accused of the murder of her friend, Patricia. Her husband is convinced she is the killer, and decides to have his children grow up thinking that she is dead. Twenty years later María is released for good behaviour. She returns to her husband, Esteban, and asks him to re-marry her so that she can be close to her children. Esteban initially resists-for he plans to marry the young and sultry Ana Rosa—but eventually assents to the remarriage, as the distance, resentment and distrust between him and María dissipate. María’s children, not knowing that she is the same woman whose adored image on the wall of the family mansion they worship, see her as an impostor who wants to take the place of their touted 'late' mother. Gradually, however, they begin to like her and her husband falls in love with her again. María must choose between telling her children the truth and having the family she always wanted or to find the real killer of her friend to exculpate herself. María is clearly the incarnation par excellence of the good, holy mother; she is constantly linked in many tear-jerking scenes to la Virgen de Guadalupe. And yet she needs to prove her innocence, becoming the Mexican archetypal madre sufrida in the process, which will inevitably lead to redemption. ${ }^{3}$

\footnotetext{
${ }^{3}$ Marit Melhuus (1996) talks of the redemptive qualities of suffering and motherhood in Mexican gender ideals.
} 
The hunt for the real killer is an element seeded from the very beginning: who really murdered Patricia? Televisa kept the audience of La madrastra guessing by teasingly suggesting a range of possible killers among the avowed villains at the show's debut: Alba, the aunt of Esteban; Fabiola, who is besotted with Esteban; and, Bruno, the husband of Fabiola; among others. All these characters are variations on the villain theme, and yet they are ambiguously so, as their avaricious desires drive them more than any essential evil attribute. The traditional villain — especially when male-is evil incarnate, perverted, symbolic of a corrupt order that threatens good, a contradictory will that murderously asserts itself. The villain discovered at the end embodies precisely these things. The inspector Muñoz and María’s attorney Luciano (who is secretly in love with her) accompany us on the mission to discover the true killer’s identity.

At the last minute, Televisa decided to extend the telenovela by another ten episodes, thus keeping viewers transfixed on how things might end, which accords with Robert C. Allen's comments on the teleological thrust of the novela form. Public discussion only intensified. By now, the attorney Luciano, Esteban’s girlfriend Ana Rosa, and a bellboy had added to the body count of a killer still on the loose. Finally, the cliffhanger scene in the last episode makes clear who the killer is, and what his motivations and Manichean contradictory double psychology are, when María herself becomes his next potential victim. ${ }^{4}$

\section{Televisa and its Interests}

Before considering the foregoing climactic scene with respect to its depiction of crossdressing - something to which we will return shortly—it is useful to locate this representation in the context of its producer's influence and interests. As Mexico’s largest stakeholder in media enterprises, Televisa currently owns around 75 percent of the total market making it the largest media company in the Spanish-speaking world. Its programming airs in the U.S. via Univisión, with whom Televisa has a contractual agreement. Televisa is a media empire with many transnational networks. Headed by Emilio Azcárraga Jean since 1991, the third in a dynastical succession in the same Mexican family, Televisa is responsible for a range of television production and distribution, as well as programming for pay TV, direct to home satellite services, cable,

\footnotetext{
${ }^{4}$ See Video 1 (file accessible via PORTAL), and Appendix 1 for a script summary of scene.
} 
radio production and broadcasting, and feature film production and development across the Americas. Its relations with Univisión go back to the 1960s; Televisa has been a long time supplier of programming to the New York-based company, whose production is centred in Miami. In spite of its diverse interests and influences, telenovelas continue to function as the backbone of the company's business and creative activities.

Content-wise, Televisa programming has a long history of portrayal of sexual minorities_-gays, lesbians and travestis — in comedy and variety routines and other forms of entertainment which are sensationalistic in nature and draw on stereotypes, according to Mónica Taher, director of the Media Communications group of GLAAD, the Gay and Lesbian Alliance Against Defamation (Anodis 2006). ${ }^{5}$ In April 2006, GLAAD joined with the Mexican-based group MOVEMOS, the Movimiento en Medios Por la Objetividad en Temas de Orientación e Identidad Sexual (Movement for Media Objectivity in Matters of Sexual Identity and Orientation), to meet with representatives of Televisa and the other major Mexican networks in order to initiate open dialogue over the contents of representations of gays, lesbians and transgender people in their programming (Anodis 2006). Even though Televisa states in its standards of programming that, 'En Televisa creemos en la dignidad humana y en el respeto a la persona.....En Televisa siempre seremos respetuosos y promotores de los Derechos Humanos, ${ }^{6}$ its advertising of the cliffhanger ending in which the killer would be revealed and its use of cross-dressing in psychopathological terms would seem to indicate otherwise (Fundación Televisa).

Such uses of travestis and transsexuals as morbid television spectacles are not restricted to La madrastra. Notably, the now-defunct comedy skit show, No manches, also from Televisa and led by Omar Chaparro, featured a segment that made fun of trans sex workers employing a freak show scenario of a travesti with three breasts. Another segment of the reality show Otro Rollo, called Buscando a Memo, gained ratings via the

\footnotetext{
${ }^{5}$ GLAAD, a U.S.-based group, was founded in New York City in the wake of the AIDS crisis, which also generated a 'crisis in representation' around alternative sexualities and sexual practices. According to its website, GLAAD is a non-profit Lesbian, Gay, Bisexual and Transgender (LGBT) activist group 'dedicated to promoting and ensuring fair, accurate, and inclusive representation of individuals and events in all media as a means of eliminating homophobia and discrimination based on gender identity and sexual orientation' (Gay \& Lesbian Alliance Against Defamation).

6 'At Televisa we believe in human dignity and respecting people....At Televisa we always respect and promote Human Rights.'
} 
presentation of a set of beautiful female contestants among whom one is a transgender individual. The premise of the series is for the audience to guess which one is really a 'man in disguise,' even though the person in question lives and has lived full-time as female. Given the success of La madrastra's finale and the barrage of comments it produced, ratings would seem to be more at stake than any respectful treatment of the topic of travestis and travestismo.

Stuart Hall, referred to at the beginning of this article, posits that the meanings intended by producers - in this case, Televisa-do not come in the form of identifiably single beliefs, but rather as cultural codes that respond to public perceptions and the interests of power and dominance (1980: 129). Sociologist Steven Seidman, refining Hall's work, explains that these codes in media are often inscribed binaristically, in terms of majority/minority, normal/abnormal, moral/decadent, healthy/sick, and so on.

Moreover, the media often classifies people in accordance with categories of race, gender, nationality or sexuality. It then frequently corresponds these categories to the above binaries. Thus the category 'homosexual' or 'travesti' is attached to 'abnormal,' 'decadent,' 'sick,' and heterosexual and gender-normative takes the first set of positive qualifiers. Importantly, notes Seidman, '[t]he media does more than influence individual attitudes. It legitimates an unequal social order; it defines the moral boundaries of a society and thereby specifies what practices are acceptable, healthy, normal and good' (2004: 137).

In its dualistic world of the novela, La madrastra fulfils very well these potential effects, as well see by the final scene. The final episode in which Demetrio is revealed both as killer and cross-dresser, activates notions of sexual perversion, criminal pathology and transvestism, notions whose terms of mystery, concealment and intrigue recur again and again. An explanation is given by Demetrio himself as to his motives for cross-dressing and his traumatised psyche, that is, that any and every woman he has known has denigrated, insulted and humiliated him to such an extent that he has begun to despise himself and his masculine persona. María accuses him of being sick, a point that Demetrio does not negate. The psychological pretext for his taking on a feminine identity is thus communicated diegetically through dialogue as a response to his inner conflict with his male self. His cross-dressing as grotesque and mythic transformation in all its menacing power is semiotically encoded via the visual aspects of the scene: the 
apparition of a cross-dressed stalker dressed in red, whose symbolically rich garb is matched by blood-red lacquered nails. Red represents the colour of the femme fatale, possessive of a deviant rapacious sexuality; it suggests threat, alarm and strident scandal.

The full impact of the mediatic construction of cross-dressing and the propping up of dominant knowledge frameworks, however, is to be found not just in the novela as text but also in the whole media environment itself, a large portion of which belongs, perhaps uncoincidentally, to Televisa itself. It is also to be found in the social world, one mediated by a deeply ingrained fear of travestis, named by activists travestophobia, as well as the fascination with the putatively 'abnormal' and the morbid spectacle of its high-rating mediatic materialisation. Such elements ensured the crossover potential into other genres of production and sense-making, even as the novela drew to its close. Some examination of cross-dressing in the Mexican cultural imaginary itself and travestophobia is necessary in order to unlock the interpretative power of $L a$ madrastra's imagery in its socio-historical context.

\section{Cross-dressing in the Mexican Cultural Imaginary}

The ideas about cross-dressing that connect it to abnormal psychology, deception and even violence run deeper than contemporary soap opera, comedy or variety shows. ${ }^{7}$ The placement of crossgendered acts and identities into the realm of perversion, dissimulation and criminality displays a clear genealogy in Mexican culture that can be traced in many arenas: in the depositions of medico-legal experts as far back as the 1880s, as well as in the early incarnations of today's scandal sheets and the crónica policíaca.

The dying years of the nineteenth century and the dawning of the twentieth foresaw the intense scrutiny and taxonomisation of subjects in the public gaze who differed from certain standard norms in Argentina, Mexico, Nicaragua and other places, notes Argentinian sociologist Josefina Fernández, author of Cuerpos desobedientes: travestismo e identidad de género, a major study of travestis in Argentina that provides a history of their discursive inscription in medico-legal discourse (2004: 25). Emergent

\footnotetext{
${ }^{7}$ Los Sánchez, a situation comedy that features a travesti character, Libertad, who is treated sympathetically, appears to be a recent exception to the rule. In spite of this, she still occupies a rather slapstick and peripheral function to the main action at hand in the series.
} 
homosexual and travesti subcultures were targeted by lawmakers, criminologists and medical professionals. Same sex erotic practices, cross-dressing and cross-living behaviours became discursively inscribed as a sort of person whose nature was considered aberrant, deviant, and gender ambiguous. Further, homosexual and travesti subcultures were associated 'scientifically' with crime, grouped alongside prostitutes, professional criminals, swindlers, and violent thieves (2004: 25).

In Mexico, the first year of the twentieth century ushered in the paradigm of the crossdressed body as a shameful and scandalous body. In the famous case of $\operatorname{los} 41$, documented at length by Robert McKee Irwin (2003), police in Mexico City performed a raid on a group of upper class males or lagartijos (fops) dancing with cross-dressed partners - and ignited the public imagination around questions of homosexuality, transvestism and decadence. This case inaugurated notions that persist in public discourse on travestis in many locales: cross-dressing and cross-gendering as a form of dangerous liminality, depravity and duplicity.

Recent work by Julia Serano (2007) and Talia Mae Bettcher (2007) explores the framing of transgender bodies and identities by mainstream U.S. culture in terms of the appearance/reality dichotomy, in which cross dressing or cross-living subjects are understood as committing a deception or creating an illusion. When the appearance of one's gender presentation is determined to be at odds with the 'reality' of one's sexed body (genitalia), the charge of deception is levelled at transgender people. As Bettcher illustrates:

Foundational to this appearance/reality contrast and the related deceiver/pretender bind is a representational relation that obtains between gender presentation and sexed body (that is, genitalia). Gender presentation is generally taken as a sign of sexed body, taken to mean sexed body, taken to communicate sexed body. And it is precisely for this reason that transpeople who 'misalign' gender presentation and sexed body are construed as either deceivers or pretenders. (2007: 52-53)

Transphobic language and acts of violence often hinge on the rhetoric of appearance versus 'hidden reality', as Bettcher describes in relation to the well-known case of the murdered young U.S. Latina transsexual, Gwen Araujo, whose assailants invoked the trope of deception as a justification for murdering her. A similar rhetoric operates in the inscription of travestismo or cross-dressing as elaborate charade or ruse. While such rhetoric often operates in both U.S. and Latin American contexts, the associations of 
criminality, however, are particularly strong in Latin America historically. The culturally specific nature of their deployment thus requires emphasis.

In the contemporary scene, the work of Leticia Sabsay (2002) considers in some depth the mediatic depiction of travestis in the Argentinian context, a context marked by juridical contestation in which the terms of morality, social danger and the social good were greatly implicated. ${ }^{8}$ Sabsay found a visible dichotomy of 'us' versus 'them.' 'Us' were the moral majority groups concerned about the threat to their property values and livelihoods by the presence of travestis in their neighbourhoods and the reputed corrupt influence it would have on their middle class children.

Besides the media work done by Sabsay, very little has been done specifically on the representations of travestis in any television or press genres besides that conducted by human rights and international LGBT advocacy groups with branches in Latin America. The research of Andrew Reding (2003), for instance, shows that images of crossdressing and cross-gendering as a form of dangerous liminality (especially linked to HIV-AIDS transmission), depravity and perversion continue to dominate in the media, particularly in the popular or tabloid press, known as nota roja, a genre that will be examined shortly.

Addressing the persistence of such formulations Fernández demonstrates that in Latin America generally there prevails the myth of the violent, marginal and criminal travesti (2004: 118), which for her puts limits on seeing travesti identity in any other way in dominant culture: they are always located socially ‘del lado de lo abyecto’ (118). ${ }^{9}$ Cross-dressing in public, moreover, has historically been actively criminalised in law, and inscribed juridically as constituting an offence to public morality and good custom. Although there currently exist no broad, analytical scholarly works that examine the history of the promulgation and application of such laws in Latin America, they have

\footnotetext{
${ }^{8}$ Like the sociologist Fernández, Sabsay (2002) analyses media depictions in the context of extensive knowledges of deviance, control, surveillance and juridical interpellation, specifically here in the context of the derogation of the Police Edicts in Buenos Aires, which had regulated travesti movements, identities and involvement in prostitution and the newly proposed (and harsher) Código de Convivencia. A major debate erupted over this in the early 1990s in which travestis achieved a hitherto unprecedented public visibility as political actors, calling on the authorities, feminists, jurists, neighbour decency groups, and so on.

${ }^{9}$ That is, 'on the abject side of things.'
} 
been studied and reported on at length in human rights circles. These laws have not only exacted an everyday toll on the movements of travestis in past and contemporary periods, they have also authorised and provided an apologia for commonly held beliefs about such subjects. Such laws, while no longer in evidence at the Federal level, can still be found at state and local levels in Mexico. González Pérez’s previously cited study documents the existence and impact of such laws in Colima. ${ }^{10}$ Moreover, and perhaps most distressingly, in towns such as Tecate, Baja California, ordinances that specifically prohibit the presence of 'men who dress as women' in the public eye, coded as an office against morality, have found renewed support and been installed where they didn’t previously even exist_and as recently as 2002 (Reding 2003: 61). Even in areas whose legal jurisdictions do not specifically proscribe the public behaviours and identities of travestis, punitive avenues made available via the regulation of prostitution and disturbance of the public peace allow the continued criminalisation of such subjects, albeit in a de facto manner.

The efforts of community activist groups against deeply entrenched criminalising and pathologising typologies of travestis emphasise the links between this cultural discourse-evidenced in legal statutes or mediatic productions—with the marginalisation and the perpetration of social and physical violence against travestis. Newspaper headlines from the tabloid and conservative press in Mexico frequently characterise travestis as aggressive, threatening and deceptive, posing an implicit link between being cross-dressing and criminal acts. ${ }^{11}$ Travesti political groups have sought to contest the kinds of images of doubleness and charade that the La madrastra most pointedly encodes, and which circulate so saliently in the national consciousness.

\footnotetext{
${ }^{10}$ In Colima, laws exist that prohibit 'spectacles' that go against the 'moral order' (González Pérez 2003: 46). Such ambiguity and vagueness provides a wide berth of interpretation for agents of the law. Articles prohibiting the presence of men 'disguised as women' and 'fooling' or 'taking advantage of others' based on gender presentation in both bars and brothels are inscribed in the penal code established in 1985 (47).

${ }^{11}$ Some examples from the Archivo (archives) of La Reforma, a major Mexican newspaper with a notably right-wing bent, illustrate this point: 'Detienen a travesti ebrio; traía droga' ('Drunk travesti arrested; carrying drugs' 2005); 'Hieren travestis a cliente en Cuauhtémoc' ('Travestis injure client in Cuauhtémoc' 2003); 'Decepciones y sorpresas' ('Deceptions and surprises’ 2003); 'Un supuesto asaltante que se vestía de mujer' ('An Alleged attacker who dressed as a woman’ 2003). While progressive newspapers such as La Jornada offer a less mordant and less stigmatising view of non-normatively gendered subjects, newspapers like La Reforma and El Universal, more popular among the viewing and reading popular classes, offer visions that are arguably more formative of mainstream conceptions of travestis.
} 


\section{Viewer Interpretations of La madrastra}

Such abject codings might not obtain their power to frame and restrict meanings were it not for the shared consensus on the aforementioned articulations on cross-gendering that is, the commonality of mental models and interpretative routines shared by producers and consumers around 'transgender phenomena' found in the context in which the novela was made. Viewer comments at the show's site on the finale are revealing: ${ }^{12}$

Lupita: deberian pasar novelas como esas que nos de consejos como esa novela que todo lo vimos como si fuera realidad gracias por poner ese tipo de novelas de la realidad.

Tere: la verdad si me sorprendio que Demetrio fuera travesti y que por eso matara a patricia para cubrir su secreto.

Rocoto: el personaje de demetrio no es homosexual ni bisexual, es un sindrome psicologico que lo ha hecho rebelarse ante su ‘yo' masculino como resultado de todas las humillaciones que ha sufrido. Vamos nuestra gente nesesita leer mas y usar el cerebro antes de escribir en un foro.

Jennifer: me solprendio mucho pq lo creia de todos menos de el y de carmela y al saberlo me sorprendi pq no lo esperaba y menos de esa forma que se vistiera de mujer y que fuera travestiiiiiiii. Travestiiiiiiii. ${ }^{13}$ (Foro La madrastra)

As Mexican journalist and transsexual activist Hazel Gloria Davenporth observes, referring to these viewers' reactions to the finale:

Según la perspectiva de quienes vieron el final de la telenovela, las personas que se travisten de hombres a mujeres 'no sirven como hombres,' son 'asesinos porque son travestis' o 'rebeldes ante su yo masculino por humillaciones. ${ }^{14}$ (Davenporth 2005)

Although Davenporth does not examine how the place and function of telenovelas in Mexico predispose them to act as frameworks for understanding real-life events and for talking about difficult and fearful subjects, following thinkers such as Marshall McLuhan, she does suggest that the images of cross-dressing as murderous disguise deployed by La madrastra - here read as outrageous but believable by viewers — have at least a suggestive potential to influence the way people think about travestismo and travestis (Davenporth 2005).

${ }^{12}$ Spelling has been retained from the original source.

${ }^{13}$ Lupita: they should show telenovelas like this one that give us advice and which all of us watched as if it were reality thanks for putting that kind of reality show on.

Tere: actually it surprised me that Demetrio was a travesti and for this reason he killed Patricia to cover up his secret.

Rocoto: the character Demetrio isn't homosexual or bisexual, a psychological syndrome has made him rebel against his masculine ego as a result of all the humiliations he's suffered. Come on people you need to read more and use your brain before writing in this forum.

Jennifer: I was very surprised because I believed it was anyone but him and on finding out I was amazed because I didn't expect it or at least not that way, him dressing up as a woman and that he was a travesti. A travestiiiiiiii! (this was written in red).

${ }^{14}$ According to the perspective of those who watched the finale, men who dress as women 'aren't worth anything as men'; they are 'murderers because they are travestis' or 'rebels against their masculine ego' because of past humiliations. 


\section{The Case of 'Mataviejitas' and Nota Roja Journalism}

Around the same time that La madrastra was drawing to its hyped finale, a real-life drama was doing the rounds: the case of the mataviejitas. Mataviejitas was the name given by the press in Mexico to a serial killer operating within the metropolitan area of Mexico City until January 25, 2006. The murders were carried out by bludgeoning or strangulation, and the killer invariably robbed the victims. The killer, initially assumed to be male, presented on some occasions as a social worker, complete with papers and uniform, and on other occasions as a health professional, donned with a stethoscope, in order to gain entry into elderly women's homes. The women often accepted the presence of la mataviejitas at their homes, being in need of economic, emotional or medical help. The killer has been attributed with a total of 49 murders. As an article from La Jornada succinctly puts it: 'El más común es que asfixiaba a sus víctimas con objetos que se encontraban en el domicilio, como un lazo de cortina, medias o el cable de un aparato electrodoméstico o de teléfono’ (Servín y Salgado 2006). ${ }^{15}$ The same article notes that the killer was so careful in their technique that only on rare occasions were traces of fingerprints found at the crime scene, and these were insufficiently partial. The attacks were planned and astutely executed. The killer was assumed to be a man, since it was imagined that only a man would be capable of the physical strength required to overcome and kill the victims (Servín y Salgado, 26 Jan 2006). Bernardo Bátiz, the chief prosecutor of Mexico City, described mataviejitas as an individual characterised by ‘una mente brillante, muy hábil y precavido’ (Becerril 2005). ${ }^{16}$

The search for mataviejitas was muddled by conflicting evidence. Various individuals implicated in separate cases of the deaths of elderly women were advanced as the serial killer; none of them proved to be the real murderer. Meanwhile the number of victims mounted: all women ranging in age from their late fifties to early nineties. On several occasions in 2005, the killer struck twice in the same month. Accusations of official ineptitude increased incrementally with public fear about the safety of mujeres de la tercera edad, a polite Mexican euphemism for older women. The crimes become more vicious: stabbing, plastic bags over the head, choking with household cable wire. The murderer even took care to burn down the house of one of the victims, their remains

\footnotetext{
15 'The killer most commonly asphyxiated his victims with objects found in the home, such as curtain ties, stockings, electrical appliance or telephone cords.'

${ }^{16}$ That is, possessing 'a brilliant mind, [being] quite clever and careful.'
} 
only identifiable by dental records. At one point the police posited that two killers might be involved, and attention was also directed to the odd coincidence that at least three of the killer's victims owned a print of an 18th century painting, Boy in Red Waistcoat, by the French artist Jean-Baptiste Greuze ('Mexico Police Hunt Serial Killer’2006). In desperation or perhaps to quell public fear, Bátiz suggested publicly that the killer might have already died, that is, by their own hand. However, the killings continued. Conflicting eyewitness accounts on seeing a stranger come and go from the victims' homes reported either a man disguised as a nurse, or a social worker, wearing a wig; conversely, the killer was reported to be a woman. On August 25, 2005, Bátiz presented two artist impressions of the killer: a figure with prominent jowls, heavyset eyes and wearing what looks like a wig, and earring studs. By October 2005, some two months after the end of La madrastra, the Mexican authorities were reporting witness statements to the effect that the killer wore women's clothing to gain access to the victims’ apartments. Bátiz announced publicly that the killer could be a travesti.

The coverage of the unfolding events is too vast to communicate in great detail in the present article; however, suffice to say that much of Mexico City was captivated by the mystery of their latest serial killer, who inspired both awe and dread. The biggest and most densely populated city in the world, where one can be alone in a crowd, haunted by the solitude and anonymity of a sea of faces, as Carlos Monsiváis describes life in el $D F$ so poetically, became the stage for a new mass drama, unreeling itself in the 'real,' like so much fact turned fiction, or fiction turned fact (1997: 31-32).

In an article published in the journal of criminology, Revista Cenipec, 'Homicidios seriales en la Ciudad de México ¿Un fenómeno viejo o nuevo?’ (2006), legal expert Martín G. Barrón Cruz considers the history of serial killers whose murderous activities have ignited the popular and academic imagination in Mexico. He profiles the lives and careers of the most famous, setting them against the violence of the urban environment of the great metropolis: its parameters of poverty, social inequality, and political exclusion whose toll is most often exacted against vulnerable minorities considered socially undesirable, but also older women in need. Barrón underlines the persistent talk around such cases and the high dosage of ultra graphic data that flows through public channels. He notes that the reporting of the mataviejitas case warrants its inclusion in the legendary social register of crime-watching and observes the tendency to the 
elevation of the killer to the status of celebrity. 'Convirtiéndose así en un tema moda, tanto del quehacer político-social como del académico...La proliferación de dicho fenómeno ha llegado a tal grado que, en algunos medios...se le conoce como 'Little Old Lady Killer ${ }^{17}$ (Barrón Cruz 2006: 159). In a similar, mordant vein, one public commentator in El Universal records their disdain at what appears to be a morbid obsession around the case. In an interesting turn, the impassioned rise to discourse around the mataviejitas serial murders is explicitly linked by the writer in El Universal to the intense and conflicted curiosity produced by telenovelas in the viewing public (Velázquez 2006).

Certainly, if there exists a national obsession besides watching telenovelas, it involves the following of crime stories in print and visual media in Mexico. Nota roja journalism constructs a kind of dirty realism. As media scholar José Luis Arriaga Ornelas defines this genre of reportage in an issue of Razón y palabra:

En una acepción general, la nota roja es el género informativo por el cual se da cuenta de eventos (o sus consecuencias) en los que se encuentra implícito algún modo de violencia—humana o noque rompe lo común de una sociedad determinada y, a veces también, su normatividad legal. Ahí caben los relatos acerca de hechos criminales, catástrofes, accidentes o escándalos en general, pero expuestos según un código cuyos elementos más identificables son los encabezados impactantes, las narraciones con tintes de exageración y melodrama, entre otros. ${ }^{18}$ (2002)

Monsiváis, musing on the genre in 'Red News,' similarly sees nota roja as framing the limits of the normal, but explains the participatory pleasures and agonies that crime narratives engender in the reading public, encouraging 'a kind of retrospection that imagines the climactic moments' intimately tied up with personal investments like jealousy, greed, the desire for loss of control and instinctual abandon that the trespass of the serial killing spree evokes (1997: 148). Interestingly, such anticipatory and emotionally heightened elements compare well with the telenovela form, characteristics identified by the telenovela scholars profiled earlier. Monsiváis pinpoints the historic function in Mexico of the spectacularisation of crimes and criminals, whose reported actions and character function as 'conversation pieces which become the joyous proof

\footnotetext{
${ }^{17}$ 'Having become a hot topic, both in academic and socio-political affairs...the proliferation of the phenomenon has reached such a degree that, in some media...the killer is known as the "Little Old Lady Killer.”,

${ }^{18}$ In general terms, the nota roja style of journalism is that genre through which events and their consequences are recounted and in which one finds depicted forms of violence - human or otherwise that break with the 'the usual' in a given society and violate its normative standards of legality. It contains criminal cases, catastrophes, accidents, and scandals in general, exposed according to media codes whose most identifiable elements are screaming headlines, narratives imbued with exaggeration and melodrama.
} 
that the reader or commentator is still alive [unlike the killer's victims], free, and more or less intact,' that is, in spite of the violence that stalks the city as imagined by such media stories (148-49). Arguably approaching the level of the popularity of telenovelas, here we see that crime stories - especially those whose discursive style relies on impact more than information - are tied up in the talk practices of everyday life. The curiosity to know the minute details of who-what-when-how-why drives the practices of consumption of these kinds of news stories. As Sandro Macassi Lavander and Francisco Ampuero Navarro (2001) demonstrate in their study of the Peruvian incarnation of such stories, the individual social drama is the point of focus - the psychological bent and motivations of the killer. Private is turned public, scandal becomes commonplace. A mixture of linguistic registers is apparent in this kind of media discourse, interpellating, as it often does, the popular sectors via colloquial and informal language use. In Mexico, several of the magazines that specialise in sensationalistic crime reporting include Alerta!, Alarma!, Presidio, De peso; the chief televisual sources for such reporting have included A sangre fría, Ciudad desnuda, Fuera de ley, and Duro y directo. Here, as always, personalities matter more than persons, and archetypes are heavily drawn upon to such an extent that the lines between novelistic fiction and documentary are blurred.

The mataviejitas case, followed in both 'serious' journalistic fora and those considered popular (and, by elitist standards, less serious) took on all the mentioned shades of the historical tendencies in crime reporting, making use of intertextual resonances from popular culture and melodramatic narrative. The inference by Chief Public Prosecutor Bátiz that the killer could be a travesti—'a man dressed as a woman'—ignited public attention and its cultivated love of melodrama and scandal. The notion that the killer was a 'man dressed as a woman' persisted even in news sources such as La palabra that openly discredited Bátiz’s seeming ineptitude and inability to capture the killer (González 2005). Even after the raid against travesti prostitutes, the progressive newspaper La Jornada still raised the issue of whether the killer was a woman or indeed a travesti (Salgado 2005). As a communicative chain that projected the image of crossdressing criminality, the terms killer and travesti were subject to endless citation over several months. Television shows such as Mujer, casos de la vida real, employing a faux-documentary style, complete with fictional reconstructions, drew on pop psychology notions, mixed with the kinds of stereotypical ideas around cross-dressing familiar to us from the horror/psychological thriller genre, whose tradition in the 
English-speaking world spans Alfred Hitchcock’s Psycho, Hammer Studios’ Dr Jekyll and Sister Hyde and Brian De Palma’s classic flick, Dressed To Kill—all films which feature transgender people as killers. ${ }^{19}$ The reportage also compared the case to another which had shocked Parisians decades before, the famous case of Thierry Paulin, dubbed the Monster of Monmartre, a killer of elderly women who was involved in a life of intensive drug use, parties, cruising on the gay scene and nightclub drag performance. That he killed his victims en homme was irrelevant; in the Mexican context parallels between the French case and the current framing of mataviejitas as a cross-dresser made the association between travestismo and killing inevitable, together with the deeply embedded cultural associations around cross-dressing itself.

As was the case in the cited viewer reactions after the finale of La madrastra, in public talk around the real-life serial killer much comment was delivered on mataviejitas' proposed psychodrama and inner hatred of female figures, especially of the older generation. Director of the Instituto Nacional de Ciencias Penales, the National Institute of Criminal Sciences, Miguel Ontiveros Alonso, argued that mataviejitas was 'un hombre que ha decidido disfrazarse de mujer. El homicida podría disfrazarse de cura, de plomero, de enfermera, vendedor de biblias, etcétera, pero escogió hacerlo de mujer, lo que denota un importante conflicto con las figuras femeninas' (cited in Davenporth 2005). ${ }^{20}$ This comment appears to draw major inspiration from the character of Demetrio as depicted in La madrastra. What wasn't conceivable in the closed circuit of signifying practices around the case was that mataviejitas could simply be a woman: a hefty and strong one, a former lucha libre wrestler at that, but clearly not a crossdresser.

I would suggest that the screening of La madrastra renewed and made fresh in the public mind the pre-established mental and social models of the pathology of cross-

\footnotetext{
${ }^{19}$ Mujer, casos de la vida real is a talk show, produced by Televisa and hosted by Silvia Pinal, which has been running since 1985, the year of Mexico City's great earthquake disaster. Born in the context of a disaster of tremendous physical, emotional and discursive impact, it seeks to present matters of social relevance to the community: the pressing, the hard-hitting, and the 'up close and personal.' The program has an investigative yet informal current affairs style and often covers questions such as prostitution, sexual violence, drug addiction and trafficking, and other assorted controversies drawing national attention, as well as the fortunes and misfortunes of immigration and less-than-legal cases of border crossing to the U.S.A.

20 'a man who decided to disguise himself as a woman. The killer could have disguised himself as a priest, a plumber, a nurse, a bible salesman, etc, but no, he decided to do it as a woman, which denotes an important conflict with female figures in his life.'
} 
dressing and its murderous criminal intent: prototypes faithfully consonant with the novela's world of black and white morality, its core of family values and normality, represented in La madrastra by María and her family, which is threatened by the 'deviant' transvestite other. María is a pure, faultless woman-the essence of heterosexual, maternal ambition. Initially the one falsely assigned as impostor-killer, a transvestite is revealed to be the 'real' fearful embodiment of the duplicitous evildoer. In this way, representing the abject of which María is cleansed, Demetrio is quite otherwise - a shadowy manifestation which invades the family mansion and the heart of the family construct with its parent-child dyad. Moreover, the comments by Lupita, included earlier in the viewer interpretations section, make clear that the episode was seen by some as depicting a horizon of possibility_offering valid information, which we could relate to reality.

The schema that the novela, the talk around it and that the mataviejitas case inscribe goes thus: one cross-dresses to disguise oneself and in order to commit a crime. It relates to dishonesty, deviousness and an inner conflict. Rocoto's analysis, another of the viewers mentioned previously, is not dissimilar to that of the penal expert, Ontiveros Alonso, which echoes the words used by Demetrio to explain why he cross-dresses. Captivated by this finale, then, and the case of the mataviejitas killer still on the loose, one could assert that the public read across genres and in interpreting real-life events, applied similar reading codes to both the motif of transvestism deployed by the novela, the codes of pop psychology and criminal intent found in nota roja journalism and the dark forces that threaten in the melodrama of everyday existence in Mexico City, a city haunted by its self-conception of the violence of a crowded but anonymous polis. This viewing public consisted of the various Lupitas across Mexico, the witnesses who attested to having seen a cross-dressing killer, the Chief Public Prosecutor Bátiz himself, crime expert Ontiveros Alonso and, finally, the federal police who over two days in October 2005 conducted a series of raids on travesti prostitutes working in the streets, seeking to find mataviejitas among them.

In these raids, scores of travesti and transsexual sex workers in Calzada de Tlalpan and Avenida Insurgentes were beaten and forced to board police vans. They were booked and taken to the Benito Juárez police station, where they were fined, photographed and finger printed, as arresting officers looked for evidence of the mataviejitas among them 
(Jiménez \& Sánchez 2005). Although officially Bátiz claims they were responding to neighbourhood complaints about prostitution in the area, those travesti and transsexual people so victimised report otherwise (Jiménez \& Sánchez 2005). Representatives of the travesti sex workers rights group 'Ángeles en busca de la libertad’ protested these raids with the motto 'no somos machos, pero sí somos muchas’ (Disforia de género 2005).

The foregoing phrase- ‘we're not men, but many'—ironically encapsulates the key issue which places mainstream perceptions of travestis and travestis' own self-concepts very much at odds. Travestis rarely relate to the popular vision of themselves as mere 'men dressed as women.' Although they do not always claim the subjectivity of women, unlike many male-to-female transsexuals, they nevertheless do not see themselves as conventional men. Biologically male, perhaps, and homosexual because of their (selfidentified) erotic preference and activities with the same biological sex, but socially, and in terms of gender expression, many travestis frequently show a strong disidentification with the concept of 'men' and masculinity. Studies like the Brazilian-centred one of Kulick (1998), as well as the previously mentioned work of Prieur and González Pérez, both of which refer to Mexican locales, show that travesti femininity is deeply attached to the cultural logics of so-called passive role homosexuality, in which those who penetrate are considered men, while those who are receptive are more like women. Given this, and the travesti preference for the receptive role in sexual relations, their lovers are 'men,' but they themselves—according to self-concept—differ from this norm. Prieur's subjects relate to themselves as 'like women' and seek masculine partners whom they term mayates. Prieur reveals via interviews what her subjects were like as children and when they first realised their femininity and attraction to males. Their femininity was obvious to themselves and others due to their fondness for toys and play scenarios culturally particular to girls, as well as in their marked interest in girls' clothes and their softness. Most of her respondents claim they were born that way. In González Pérez’s study, although they are travestidos gays, many consider themselves muchachas, not 'men,' per se. And yet the public imagination at the conjunction of all the media forms studied in this article and the talk they provoked posits that cross-dressing as a phenomenon is about disguise, trickery as well as the intent to assault or kill. And this is the crux of the matter-the gap between dominant understandings of cross-dressing and cross-living people as seen in the novela, the mass media and police accounts, and the understandings these subjects have themselves, as 
people who cross-identify and live in feminine mode on a daily basis. ${ }^{21}$

This disjuncture between how they are seen by others (thanks to the motif of the transvestite as criminally insane, as duplicitous invader) and how they see themselves compellingly illustrates Bourdieu's notion of symbolic violence, which Josefina Fernández, cited previously, also advances in understanding the cultural stigmatisation of travestis in Latin America. Symbolic violence is a form of violence that permeates the social worlds in which travestis move. Of course, this symbolic violence is not just enacted by La madrastra's cross-dresser as murderous disguise imagery; it is also articulated in the talk around the episode and expert and popular nota roja versions of mataviejitas as a travesti, in other media texts historically, as well as in time honoured anti-travesti laws. Yet as we see by the example of the telenovela representations and interpretations of the mataviejitas killer, symbolic violence can have very material consequences - the public abuse and police rounding up and fining of real-life trans people, to whom the soap opera's imagery and the public talk inevitably remits. As Bourdieu submits, symbolic violence works not just to relegate subjects to positions of inferiority, to place them at risk of other forms of violence, to deny them resources and participation in mainstream cultural life or limit their social mobility and aspirations, but rather it also inhabits the very individuals it acts against - thus reinforcing their marginalisation (Bourdieu \& Wacquant 1992). ${ }^{22}$ In the same way that homophobia or the image of the drug addict may be internalised, travestis in the context of representations like these confront not simply public opprobrium, criminalisation and police persecution, but risk becoming imprisoned themselves in the cultural ideas of what a travesti is. As such, and for a multitude of good reasons, resisting symbolic

\footnotetext{
${ }^{21}$ Bettcher's comments about how transpeople are perceived by mainstream culture, regardless of their own self-concepts, are useful here: 'Insofar as transpeople are open to constructions as 'really an x,' (appearances notwithstanding) we will immediately find ourselves represented in ways that are contrary to our own identifications. This construction literally reinscribes the position that genitalia are the essential determinants of sex by identifying that essential status as the 'hidden reality or truth of sex,' Through such a construction, we will invariably be represented as deceivers or pretenders' (2007: 51).

${ }^{22}$ Bourdieu first introduces the concept of symbolic violence briefly in The Logic of Practice (1990). He links it to misrecognition, that is, the tendency of subjects not to recognise that this form of violence is exercised against them, as it appears to be the natural order of things. Symbolic violence, says Bourdieu, constitutes a 'gentle, invisible violence, unrecognised as such' (1990: 127). Bourdieu later gave the concept more development and application, showing how symbolic violence works in the interests of the dominant group to extend their world views and concepts of the 'normal,' the 'natural' to all subjects in such a way that it is rarely questioned. In being so commonly embodied and integrated in cultural forms and practices, it obtains the appearance of being real and yet it is a force, a set of contestable knowledge, whose ideological workings may be hidden but which can be exposed. Although it is continually reproduced it may be interrogated, interrupted and denaturalised.
} 
violence is a difficult yet urgent enterprise.

\section{Concluding Remarks}

I started this article raising the question: do representations have material consequences for specific groups of people in society? And if so, how does this occur? Highlighting the structure and place of the telenovela in Mexican society reveals how Mexican novelas often work around a moral centre and deploy Manichean visions of the world. Their insertion into everyday life renders them into points of interrogation and mediation not simply of the content of the novela itself, but also the outside world. They constitute an important venue through which viewers make sense of modern life and current events. They become intertexts for reading both other media texts and the social text. They work ideologically and their melodramatic mode demands a willing suspense of disbelief, as well as viewer identification and complicity. Their viewing public is vast and considerable hours of the day are devoted to screening the serials and re-hashing them afterwards. As semiotic and symbolic forms, they are involved in the organisation of emotional, domestic and social life.

Images of cross-dressing which connect it to deception, criminality and pathologyimages disseminated by the final episode of La madrastra-were taken up and recirculated in talk around the program and in the context of the mataviejitas case. Even the country's highest legal experts and justice officials appear to have read across this discursive panorama so powerfully and viscerally invoked for mainstream Mexico by the vision of the cross-dressed Demetrio. In a country where little-if any—alternative knowledge about cross-dressing, cross-living and travesti subjects is available, this cross-over reading, if not the only possible one, was at least the most predictable, given the conjunction of generic elements, the tabloid reportage of the mataviejitas case, and the discourse evinced in her criminal profiling in the public domain. The evidence presented in this article suggests that this reading was the hegemonic one.

Police were highly criticised by human rights defenders for their raids on travesti prostitutes, and yet their actions could be seen as part of the implementation of the commonly agreed upon terms of symbolic violence which the novela and public talk negotiates - that is, that travestis are killers or mentally unstable, that their very embodied identity constitutes a ruse or deception, a manifestation of sickness, a Gordian 
knot of psychic doubleness and splitting. This is the reason why I have analysed the novela in terms of its social field of interaction, following critics like Martín Barbero. As in many other countries in which vast commercial media environments obtain, in Mexico, where 'real life' is subject to mediatic (re)construction and the practices of framing that life are so suffused with the codes of melodrama and nota roja journalism, the public abuse of travestis as the targets of blame and police fury offers a vivid instance of the ways in which representations can insinuate themselves socially, organise the imaginary and produce real, lived effects. And if the experience of contemporary urban life in Latin America is increasingly scripted by the media's use of fear’s vocabulary, a phobic lexicography which separates the (sexually) normative from the 'aberrant,' wherein travestis become the usual suspects, it unsurprising that Demetrio the killer crossdresser gains status as a master text for expressing fear of the other. That other here-the duplicitous and murderous travesti, ever unreal-emerges at the confluence of pre-established mental models and interpretative codes, in an informational landscape haunted by narratives where strangeness and difference become the embodiments of risk and violence, stalking the city dweller with half-imagined and syndicated nightmares in constant superimposition. ${ }^{23}$

\footnotetext{
${ }^{23}$ Citizens of Fear: Urban Violence in Latin America, the collection of essays edited by Susana Rotker (2002) on the subject of violence, crime and the Latin American city, approaches the persistence and haunting presence of violence, both real and fearfully projected, within the spaces of the megalopolis and its mediascapes. Rotker says in her introduction, 'Cities Written by Violence,' that: 'The city has been transformed into a space of vulnerability and danger.... What I am interested in narrating here is...the generalized sensation of insecurity that taints the Latin American capitals, the sensation that has changed the ways people relate to urban space, to other human beings, to the state, and to the very concept of citizenship' (2002: 8). In this sense, Mexico City is just one among several Latin American cities seized by its own sense of vulnerability and danger, whose impacts are increasingly seen in social relations, and whose register is the real turned hyperreal. The present article therefore elucidates just one paradigmatic example of what the findings of scholars like those included in Rotker's volume point to.
} 


\section{Appendix: Video 1 Demetrio Revealed—Scene Dialogue Summary in English}

MARIA: Demetrio...No, no...

DEMETRIO: No one is going to save you. Ssh! Quiet!

MARIA: Demetrio, hand yourself in, you're not going to gain anything by killing me.

DEMETRIO: Of course I will...I'll gain my revenge...because of your stupid talent for finding me out. You're the one who’s truly guilty for everything that's happened.

MARIA: Me guilty?

DEMETRIO: Yes, you.

MARIA: But you're the one who ruined my life, you destroyed everything I had...because of your crime I spent twenty years in prison!

DEMETRIO: The same twenty years that we lived peacefully and happily until you returned. Why did you do it? Why did you have to return? That's why I have to kill you.

MARIA: Demetrio, Demetrio, you're sick, you need help.

DEMETRIO: Sick? Yes, I'm sick but it's the fault of all the women I've known. They always denigrated me, insulted me, humiliated me until they managed to make me hate myself. That's why I have to turn myself into someone else, so I can respect myself.

MARIA: Demetrio, Demetrio...I'm not part of that group of women you've mentioned. Not once did I insult you, not once did I hurt you or humiliate you!

DEMETRIO: And you've returned...I killed Patricia....and I don't want my son to feel the pain of finding out... that's why I have to kill you too! 


\section{Reference List}

Allen, R.C. 1995, 'Introduction,' in R. C. Allen (ed.), To Be Continued: Soap Operas Around the World, Routledge, New York, 1-26.

Anodis. 2006, 'Dialogan grupos gays con directivos de Televisa,' Anodis.com, 5 abril. Online. Available: http://www.anodis.com/nota/6752.asp (Accessed 5 Sep. 2006).

Aprea, G. y Martínez Mendoza, R. 1996, 'Hacia una definición del género telenovela,’ en M. Soto (coord.) Telenovela/telenovelas: Los relatos de una historia de amor, Atuel, Buenos Aires, 17-30.

Archivo, La Reforma. Online. Available: http://busquedas.gruporeforma.com/reforma (Accessed 12 Sep. 2006).

Arriaga Ornelas, J. L. 2002, ‘La nota roja: “Colombianización” o “mexicanización” periodística,’ Sala de Prensa, vol. 2. Online. Available: http://www.saladeprensa.org/art375.htm (Accessed 5 Sep. 2006).

Baker, R.W. (dir.) 1971, Dr Jekyll and Sister Hyde, Hammer Studios.

Barrón Cruz, M. G. 2006, 'Homicidios seriales en la Ciudad de México. ¿Un fenómeno viejo o nuevo?,' Revista Cenipec 25 (enero-febrero), 141-64.

Becerril, C.A. 2005, ‘El “mata viejitas” ... libre, brillante y precavido,' El Mundo Austin, 13 octubre. Online. Available: http://www.elmundonewspaper.com/news.php?nid=2512 (Accessed 14 Sep. 2006).

Bettcher, T.M. 2007, 'Evil Deceivers and Make-Believers: On Transphobic Violence and the Politics of Illusion,’ Hypatia: A Journal of Feminist Philosophy, vol. 22, no. 3, 43-65.

Bourdieu, P. 1990, The Logic of Practice. Polity Press, Cambridge.

Bourdieu, P. \& Wacquant, L. 1992, An Invitation to Reflexive Sociology. University of Chicago Press, Chicago.

Cabral, M. (A. I. Grinspan) \& Viturro, P. 2006, '(Trans)sexual Citizenship in Contemporary Argentina,' in P. Currah, R. M. Juang, and S. Price Minter (eds), Transgender Rights, University of Minnesota Press, Minneapolis, 262-73.

Cabrujas, J.I. 2002, Y Latinoamérica inventó la telenovela, Alfadil Ediciones, Caracas, Venezuela.

Davenporth, H.G. 2005, 'De asesinatos, autoridades, travestis y telenovelas,' Notiese, 21 octubre. Online. Available: http://www.notiese.org/opinion.shtml?cmd\%5B55\%5D=x-554dc3b8c3b9c3bcc5bec39d7b221e5bc2 (Accessed 8 April 2006).

De Palma, B. (dir.) 1980, Dressed To Kill, Cinema 77 Films.

Disforia de género 2005, 'Trans de México protestan en derechos humanos por acción policía caso asesino ancianas,' Disforia de género. Online. Available: http://www.disforiadegenero.org/modules.php?name=News\&file=article\&sid=238 (Accessed 15 Sep. 2006).

Fernández, J. 2004, Cuerpos desobedientes: Travestismo e identidad de género. Edhasa, Buenos Aires.

Foro La Madrastra n.d., Online. Available: http://www.networks54.com/Forum/376482/page-76 (Accessed 12 July 2006).

Fundación Televisa n.d., 'Nuestra visión.’ Online. Available: http://www.esmas.com/televisa/notas/nota_8.html (Accessed 12 Sep. 2006).

Gay \& Lesbian Alliance Against Defamation (GLAAD), n.d. 'Mission.' Online. Available: http://www.glaad.org/about/mission.php (Accessed 22 Oct. 2007).

González, H. A., 2005, 'El mataviejitas ataca de nuevo,' La palabra.com, 4 octubre. Online. Available: http://esp.mexico.com/lapalabra/una/21414/el-mataviejitas-ataca-de-nuevo (Accessed 24 Oct. 2007).

González Pérez, C. O. 2003, Travestidos al desnudo: Homosexualidad, identidades y luchas territoriales en Colima, México. Miguel Angel Porrúa, México, D.F.

Hall, S. 1980, 'Encoding/decoding,' in S. Hall et al (eds), Culture, Media, Language: Working Papers in Cultural Studies, 1972-79, Hutchinson, Centre for Contemporary Cultural Studies, Birmingham, 128-38.

Hitchcock, A. (dir.) 1960, Psycho, Shamley Productions.

Irwin, R. M. (ed.) 2003, The Famous 41: Sexuality and Social Control in Mexico, c.1901. Palgrave Macmillan, Basingstoke.

Jiménez, G. \& Sánchez, A. 2005, 'La PGJDF detiene y ficha a 36 travestis por sospechar que alguno está vinculado con los asesinatos de ancianas,' La Crónica, 20 octubre. Online. Available: www.cronica.com.mx/nota.php?idc=208096 (Accessed 5 Sep. 2006).

Kulick, D. 1998, Travesti: Sex, Gender and Culture among Brazilian Transgendered Prostitutes. University of Chicago Press, Chicago.

López, A. M. 1995, 'Our Welcomed Guests: Telenovelas in Latin America,’ in R.C. Allen (ed.), To Be Continued: Soap Operas Around the World, Routledge, New York, 256-75. 
La madrastra 2005, Episode 120, 18 agosto [TV Series]. Televisa S.A. de C.V., México.

Macassi Lavander, S. \& Ampuero, F. 2001, Prensa amarilla y cultura política en el proceso electoral. Calandria, Lima.

Martín-Barbero, J. 1987, De los medios a las mediaciones. G. Gili, Barcelona.

Martín-Barbero, J. 1995, 'Memory and Form in the Latin American Soap Opera,' in R. C. Allen (ed.), To be Continued: Soap Operas Around the World, Routledge, New York, 276-84.

Martín-Barbero, J. 2000, ‘The Cultural Mediations of Television Consumption,' in I. Hagen \& J. Wasko (eds), Consuming Audiences? Production and Reception in Media Research, Hampton Press, Cresskill, NJ, 145-63.

Melhuus, M. 1996, 'Power, Value and the Ambiguous Meanings of Gender,' in M. Melhuus \& K.A. Stølen (eds), Machos, Mistresses, Madonnas: Contesting the Power of Latin American Gender Imagery, Verso, London \& New York, 230-259.

'Mexico Police Hunt Serial Killer’ 2006, BBC News, 11 October. Online. Available: http://news.bbc.co.uk/2/hi/americas/4332042.stm (Accessed 5 Sep. 2006).

Monsiváis, C. 1997, Mexican Postcards, Verso, London.

No manches, 2005, 'La travesti de Tlalpan con tres bubis,' [TV Series], 8 mayo. Televisa S.A. de C.V., México.

Otro rollo - Buscando a Memo 2005, [TV Series]. Univisión, Mexico.

Prieur, A. 1998, Mema's House, Mexico City. On Transvestites, Queens, and Machos, University of Chicago Press, Chicago, IL.

Reding, A. 2003, 'Sexual Orientation and Human Rights in the Americas,' World Policy Reports. Online. Available: www.worldpolicy.org/globalrights/sexorient/2003-LGBT-Americas.pdf (Accessed 20 May 2005).

Rotker, S. (ed.). 2002, Citizens of Fear: Urban Violence in Latin America. Rutgers University Press, New Brunswick.

Sabsay, L. 2002, 'La representación mediática de la identidad “travesti” en Buenos Aires,' en L. Arfuch (ed.), Identidades, sujetos, subjetividades, Prometeo Libros, Buenos Aires, 165-84.

Salgado, A. 2005, 'Del mataviejitas, 24 de 32 asesinatos: Renato Sales,' La Jornada, 17 noviembre. Online. Available: http://www.jornada.unam.mx/2005/11/17/043n1cap.php (Accessed 24 Oct. 2007).

Seidman, S. 2004, Contested Knowledge: Social Theory in the Postmodern Era. 3rd ed., Blackwell Publishing, Malden, MA.

Serano, J. 2007, Whipping Girl: A Transsexual Woman on Sexism and the Scapegoating of Femininity. Seal Press, Emeryville, CA.

Servín, M. \& Salgado, A. 2006, ‘A Juana Barraza Zamperio le gusta el rojo y prefería los martes y miércoles para matar,’ La Jornada, 26 enero. Online. Available: http://www.jornada.unam.mx/2006/01/26/042n1cap.php (Accessed 24 Oct. 2007).

Slade, C. 2003, 'Telenovelas and Soap Operas: Negotiating Reality from the Periphery,' Media International Australia (incorporating Culture and Policy), no. 106, February, 6-17.

Van Dijk, T. A. 2003, ‘The Discourse-Knowledge Interface,' in G. Weiss \& R. Wodak (eds), Critical Discourse Analysis: Theory and Interdisciplinarity, Palgrave-MacMillan, Houndsmills, UK, 85109.

Velázquez, G. 2006, 'Un thriller para el DF,' El Universal, 30 enero. Online. Available: http://weblogs.eluniversal.com.mx/wweblogs_detalle.php?p_fecha=2006-0130\&p_id_blog=2\&p_id_tema=1739 (Accessed 24 Oct. 2007).

Wieviorka, M. 2003, 'The New Paradigm of Violence,' in J. Friedman (ed.), Globalization, the State, and Violence, Alta Mira Press, Walnut Creek, CA, 107-40. 